\title{
Hotel Resort dengan Pendekatan Arsitektur Ekologis di Batu MALANG
}

\author{
Fifi Ambarwati, Agung Kumoro W., Leny Pramesti \\ Program Studi Arsitektur \\ Universitas Sebelas Maret Surakarta \\ Email : fifiambar53@gmail.com
}

\begin{abstract}
Tourism in Batu is one of the largest in Indonesia with increasing of tourism in every year. Tourism development of Batu is a part of Spatial Plan and area (RTRW) in Batu Malang 2010-2030, mentioned that one of the missions of spatial Batu, namely improving the position and role of the Batu tour of the city into a tourist hub in the estimate at the regional level, or even national, i.e. by doing addition of range objects and tourist attractions that are supported with facilities and infrastructure as well as supporting elements of the tour. The condition of the natural environment of the city of Batu became the main attraction of tourists visiting, that lies in the natural beauty of the mountains, the air of coolness that is owned, as well as the quality of the water. Appropriate accommodation facilities with natural of Batu, namely in the form of Hotel Resort that serves as a place to stay and also as a means of recreation due to the location being in the tourist areas. The design problems is creating container accommodation and recreational activities in the form of buildings on the environment-friendly natural Batu Malang by considering the concept of development that notice principle of sustainability. Objective to observe the condition of the natural environment of the city of stone that must be preserved for the sake of tourism sustainability Batu Malang. The design method used is by the application of the principles of Ecological Architecture in mass processing footprint, processing buildings, and utilities on the system and the structure of the building. Results achieved i.e. building Hotel Resort by applying the principle of Ecological Architecture so that it supports the design of energy efficient buildings as well as being able to maintain the balance of natural resources, the management of waste and garbage to be able to use again and in the waste into the environment in a condition worthy of the waste so it does not pollute the environment.
\end{abstract}

Keywords : Accommodations, Ecological Arcgitecture, Resort Hotel, Kota Batu, The Natural Environment.

\section{PENDAhuluaN}

Industri pariwisata merupakan salah satu penyumbang terbesar devisa negara di Indonesia dan juga sebagai penyumbang kas APBD suatu daerah. Kota Batu yang terletak di Kabupaten Malang Jawa Timur ini merupakan kota muda yang saat ini sedang mengembangkan sektor pariwisata serta aspek pendukung industri wisata itu sendiri. Potensi alam dan wisata yang dimiliki menjadikan Kota Batu banyak didatangi wisatawan baik domestik maupun mancanegara dengan jumlah kunjungan wisatawan tidak jauh berbeda dengan jumlah pengunjung Kota Yogyakarta dan Bali. Dari sektor pariwisata tersebut mampu mengisi kas daerah melalui APBD Kota Batu sekitar 70-80\%.

Pengembangan pariwisata suatu daerah harus diimbangi dengan berkembangnya fasilitas-fasilitas penunjang pariwisata. Pengembangan pariwisata Kota Batu merupakan bagian dari RTRW (Rencana Tata Ruang dan Wilayah) Kota Batu tahun 20102030, disebutkan dalam pasal 7 bahwa salah satu misi penataan ruang Kota Batu yaitu meningkatkan posisi dan peran Kota Batu dari kota wisata menjadi sentra wisata yang diperhitungkan di tingkat regional atau bahkan nasional, yaitu dengan melakukan penambahan ragam obyek dan atraksi wisata yang didukung dengan sarana dan prasarana serta unsur penunjang wisata yang memadai. Salah satu unsur penunjang pariwisata tersebut adalah pada bidang akomodasi yang mana mampu memfasilitasi kegiatan istirahat dan makan serta minum yang merupakan salah satu kebutuhan pokok para wisatawan.

Menurut data statistik perhotelan Kota Batu oleh Badan Pusat Statistik (BPS) Kota 
Batu 2015 disebutkan bahwa jumlah pengunjung hotel di Kota Batu naik sekitar 9\% di setiap tahunnya terhitung dari tahun 2010-2014. Oleh karena itu, pengembangan hotel dan akomodasi perlu untuk terus dikembangkan sesuai dengan Rencana Tata Ruang dan Wilayah (RTRW) Kota Batu itu sendiri. Fasilitas akomodasi yang sesuai dengan potensi alam yang dimiliki Kota Batu yaitu berupa Hotel Resort yang mana selain untuk menginap juga sebagai sarana rekreasi dan juga dikarenakan lokasinya yang berada di daerah wisata.

Perancangan sebuah bangunan Hotel Resort pada lingkungan alam Kota Batu dengan pertimbangan kondisi alam pegunungan yang masih asri dan terdapat beberapa lokasi hutan lindung serta daerah peresapan air menjadi salah satu alasan diperlukannya studi lebih mendalam mengenai perancangan wadah fasilitas kegiatan manusia dengan tetap mempertimbangkan konsep pembangunan yang memperhatikan prinsip - prinsip keberlanjutan dalam memelihara kelestarian lingkungan.

Keindahan alam pegunungan, kesejukan udara, serta kualitas mata air yang dimiliki Kota Batu merupakan daya tarik utama wisatawan di kota ini. Untuk itu dalam perancangan Hotel Resort ini menggunakan Arsitektur Ekologis sebagai pendekatan desain.

\section{METODE}

Perancangan Hotel Resort bermula dari pemikiran tentang upaya dalam menciptakan suatu wadah kegiatan yaitu berupa bangunan di lingkungan alam Kota Batu dengan tetap mempertimbangkan konsep pembangunan yang memperhatikan prinsip-prinsip keberlanjutan dalam memelihara kelestarian lingkungan.

Strategi desain yang akan terapkan pada Hotel Resort ini berpedoman pada unsur pokok Arsitektur Ekologis antara lain udara, air, api (energi), dan tanah (bumi), serta beberapa aspek penerapan prinsip Arsitektur Ekologis.

Prinsip Arsitektur Ekologis yang diterapkan pada desain antara lain adalah (Heinz Frick, 1998):

1. Ramah Lingkungan
Lokasi Hotel Resort berada di Kota Batu Malang yang merupakan daerah lereng gunung dengan kondisi lahan berkontur, aspek penerapan Arsitektur Ekologis terletak pada:

1. Pengolahan tapak (unsur tanah).

2. Pengolahan tampilan bangunan.

3. Penataan lansekap.

4. Pengolahan sistem struktur bangunan.

2. Hemat Energi

Penghematan energi (tidak terbarukan) dilakukan dengan memanfaatkan energi alam untuk diterapkan pada sistem bangunan.

1. Penghawaan alami.

2. Pencahayaan alami.

3. Penggunaan sistem gravitasi untuk pendistribusian air.

3. Pemeliharaan Sumber Lingkungan

1. Meminimalkan pencemaran udara.

2. Pemeliharaan tanah.

3. Pemeliharaan air.

4. Pencegahan terhadap erosi tanah lereng gunung.

4. Menggunakan Teknologi Sederhana

Penggunaan teknologi sederhana pada perancangan Hotel Resort yaitu pada pemilihan bahan bangunan dengan kriteria sebagai berikut:
1. Produksi bahan bangunan menggunakan energi sesedikit mungkin.

2. Tidak mengalami perubahan bahan yang dapat dikembalikan ke alam.

3. Eksploitasi, pembuatan (produksi), penggunaan bahan bangunan sesedikit mungkin mencemari lingkungan.

4. Bahan bangunan berasal dari sumber lokal.

\section{ANALISIS}

Perencanaan dan perancangan Hotel Resort di Batu Malang menerapkan prinsipprinsip Arsitektur Ekologis antara lain yaitu penyesuaian terhadap lingkungan setempat (ramah lingkungan), hemat dalam pengunaan energi, memelihara sumber lingkungan (udara, tanah, air), dan menggunakan teknologi sederhana pada desain.

\subsection{Analisis Pemilihan Tapak.}

Tujuan: 
Lokasi tapak yang mendukung dari fungsi bangunan yang akan diwadahi.

Dasar Pertimbangan:

1. Bukan merupakan area konservasi hutan lindung, dan juga bukan merupakan daerah rawan bencana.

2. Luas tapak cukup untuk menampung segala kegiatan Hotel Resort.

3. Topografi tapak tidak terlalu curam untuk kemudahan sirkulasi dan penataan ruang, serta sebagai pendukung beberapa fasilitas Hotel Resort yang membutuhkan tapak datar misalnya lapangan olah raga, sehingga tidak banyak melakukan kegiatan cut and fill pada tanah.

4. Dekat dengan kawasan wisata dan budaya.

5. Dilalui jaringan sarana dan prasarana kota seperti sistem utilitas, drainase, listrik, telepon, air dan sarana transportasi.

Lokasi tapak Hotel Resort yang terpilih berada di Kelurahan Tulungrejo, Kecamatan Bumiaji, Kota Batu. (lihat Lampiran 1) ditunjukkan peta lokasi tapak terpilih dengan jaringan sarana prasarana di sekitar tapak.

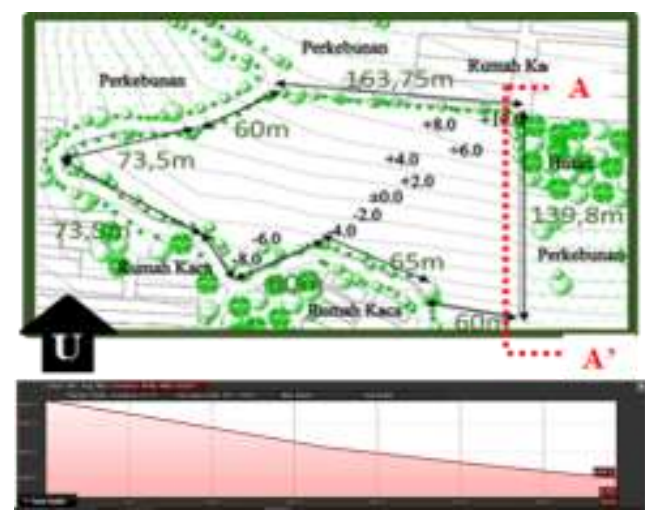

Gambar 1. Potongan Melintang Tapak

Gambar 1 menunjukkan potongan melintang tapak dari arah utara yang merupakan daerah tertinggi tapak menuju ke selatan yaitu daerah terendah dari tapak.

Luas tapak yaitu $29.360,461 \mathrm{~m}^{2}$, peruntukan lahan saat ini sebagai hutan dan perkebunan sayur. Tapak dilalui Jalan Arjuno, serta terdapatnya tanaman eksisting yaitu berupa pohon mahoni dan pohon asem. Tapak berada pada ketinggian 1360 mdpl dengan kemiringan tanah $16 \%$ (lihat Lampiran 2).

\subsection{Analisis Pencapaian Tapak}

Tujuan:

Perletakan ME (Main Entrance) dan SE (Side

Entrance) pada tapak.

Dasar pertimbangan:

1. Letak jalan utama, kondisi lalu lintas, kondisi tapak (ketinggian kontur, bentuk kontur).

2. Kemudahan pencapaian.

3. Strategis.

4. Tidak mengganggu kelancaran lalu lintas.

5. Aspek kenyamanan dan keamanan bagi pengguna.

6. Mudah dikenal.

Gambar 2 menunjukkan letak main entrance dan side entrance sebagai hasil dari analisa terhadap pencapaian pada tapak.

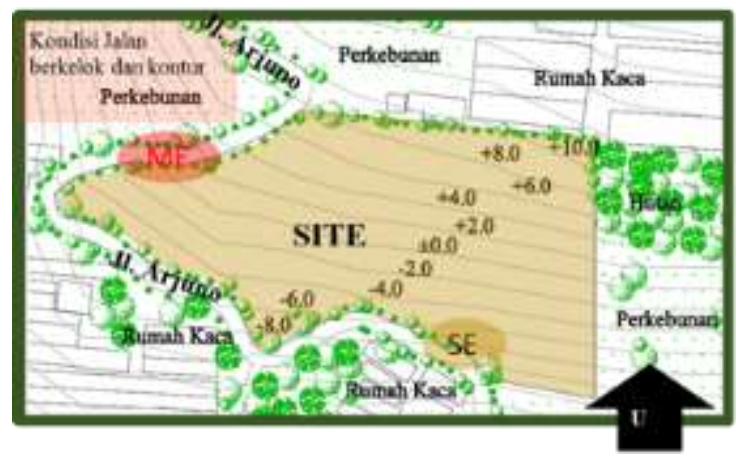

Gambar 2. Hasil Analisa Pencapaian

\subsection{Analisis Klimatologi}

Tujuan:

Pemintakatan (zoning) pada kawasan berdasarkan iklim tapak yang mendukung aspek kenyamanan pengguna.

Dasar pertimbangan:

1. Fungsi yang ditampung.

2. Kenyamanan pengguna.

3. Penghematan energi tak terbarukan.

Lokasi tapak berada di lembah antara Gunung Welirang dan Gunung Arjuno, hembusan angin yang terjadi merupakan angin gunung dan angin lembah, yang mana berhembus dari arah utara menuju arah selatan begitu pun sebaliknya.

Gambar 3 menunjukkan peletakan massa bangunan menyebar dan di putar beberapa derajat untuk mempermudah pergerakan angin sekaligus mengurangi dampak silau cahaya matahari. 


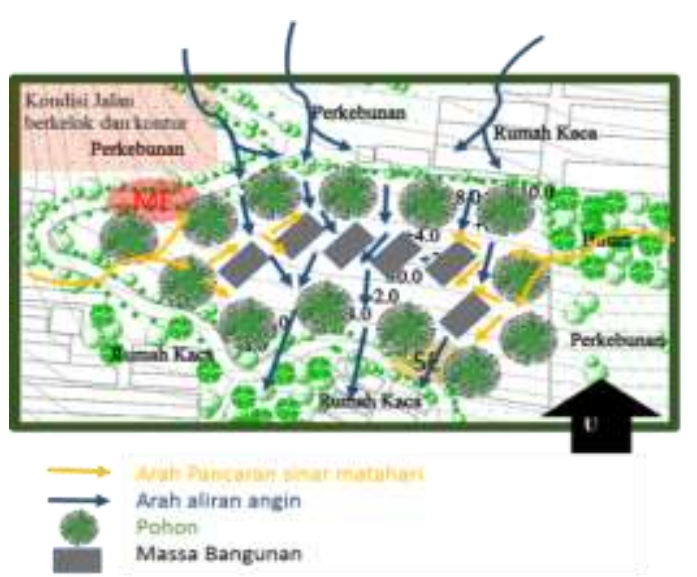

Gambar 3. Hasil Analisa Klimatologi

\subsection{Analisis Kebisingan}

Tujuan:

Pemintakatan (zoning) pada kawasan berdasarkan kebutuhan akan privasi dan ketenangan

Dasar pertimbangan:

1. Fungsi yang ditampung.

2. Kenyamanan pengguna.

Gambar 4 di bawah menunjukkan pemintakatan pada tapak berdasarkan kegiatan dan kebutuhan akan privasi dan ketenangan.

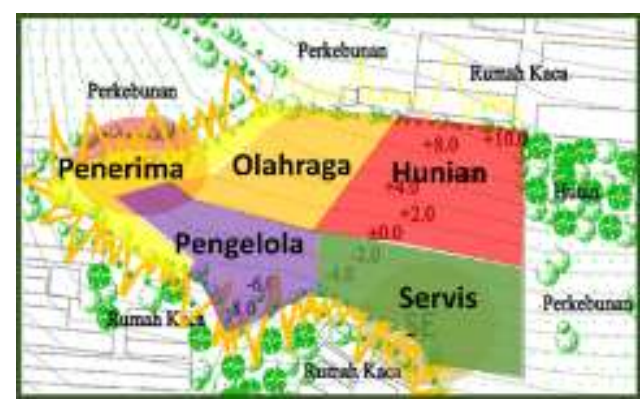

Gambar 4. Hasil Analisa Kebisingan

\subsection{Analisis Pemintakatan (zoning)}

Tujuan:

Pemintakatan (zoning) pada kawasan Hotel

Resort sesuai dengan jenis kegiatan.

Dasar pertimbangan:

1. Jenis kegiatan serta pengelompokannya.

2. Konsep pemintakatan.

3. Pencapaian tapak.

4. Sirkulasi.

5. View dan orientasi.

6. Klimatologi tapak.

7. Kenyamanan pengguna.

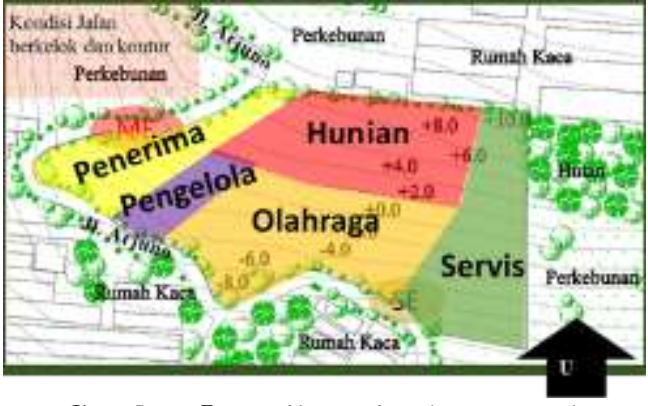

Gambar 5. Hasil Pemintakatan tapak

Gambar 5 menunjukkan hasil pemintakatan tapak berdasarkan kelompok kegiatan.

\subsection{Analisis Massa Bangunan}

Tujuan:

Bentuk massa bangunan, pola tata massa bangunan, dan tampilan bangunan

Dasar Pertimbangan:

1. Fleksibilitas dan efisiensi ruang.

2. Kedekatan ruang sejenis.

3. Pencerminan fungsi yang diwadahi.

4. Kondisi Tapak.

5. Responsif terhadap pemanfaatan sumber daya setempat.

6. Prinsip Arsitektur Ekologis.

Bentuk dasar bangunan Hotel Resort mengadopsi bentuk segi empat dengan pertimbangan kemudahan dalam pengerjaan serta efisiensi dalam penataan ruang.

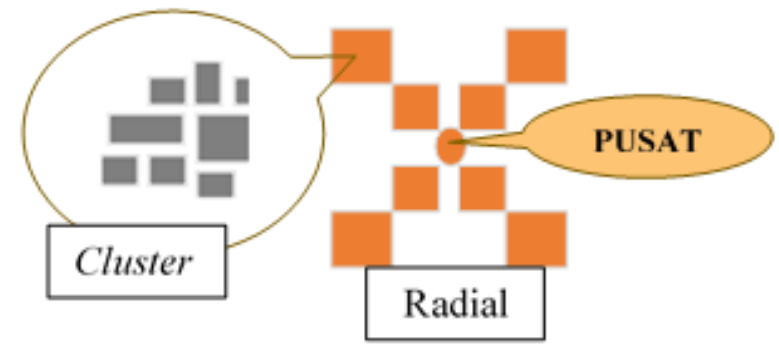

Gambar 6. Komposisi Massa

Bangunan Hotel Resort menggunakan sistem massa majemuk yaitu massa bangunan terpisah antara bangunan satu dengan bangunan lainnya sesuai dengan jenis kegiatan yang sudah dikelompokkan sebelumnya namun memiliki massa bangunan utama sebagai pusat interaksi, penyesuaian terhadap kondisi tapak yang berkontur menjadi alasan utama pemilihan sistem massa tersebut (lihat Gambar 7). 
Peletakan massa bangunan menerapkan sistem komposisi radial dan Cluster (lihat Gambar 6), sistem radial memusatkan massa bangunan di satu pusat bangunan utama di antara massa bangunan lainnya yang dihubungkan dengan sumbu linier, massa bangunan pada setiap kelompok kegiatan ditata berdasarkan sistem komposisi Cluster guna mempermudah interaksi.

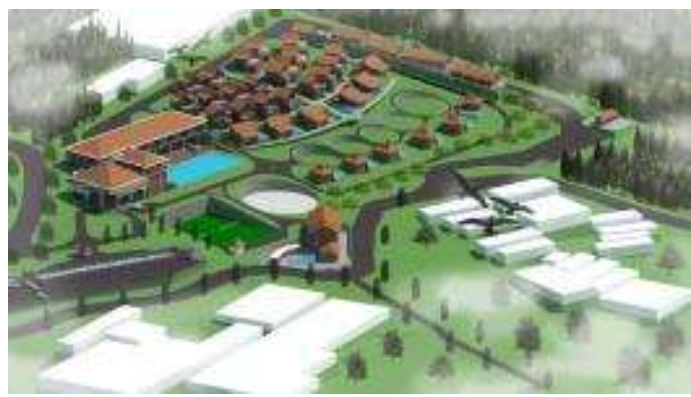

Gambar 7. Tata Massa Hotel Resort

Tampilan Hotel Resort Batu Malang terlihat pada Gambar 8, menunjukkan bahwa tampilan Hotel Resort mengadopsi tampilan Bangunan Tradisional Jawa. Bangunan Tradisional Jawa mengutamakan keselarasan dengan alam. Antara ruang terbuka dan tertutup terjalin hubungan yang akrab.

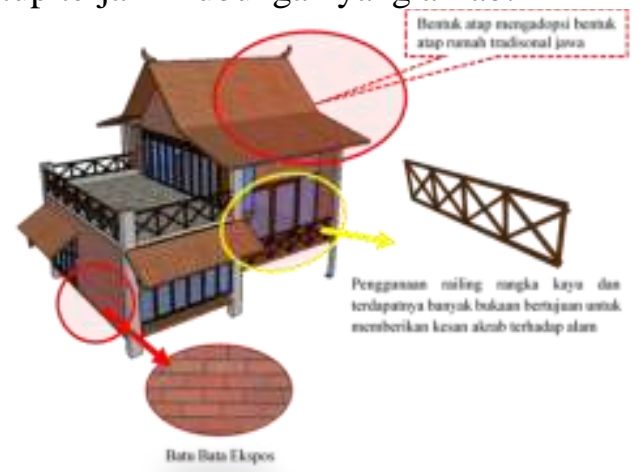

Gambar 8. Tampilan Bangunan

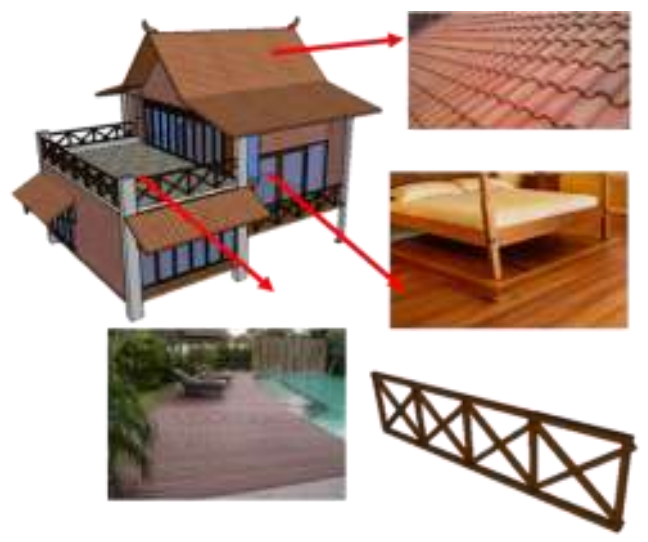

Gambar 9. Material Bangunan

Material yang digunakan antara lain adalah (lihat Gambar 9):

1. Batu bata ekspos untuk material dinding.

2. Genteng tanah liat untuk material atap.

3. Elemen luar (lantai outdoor dan railing) menggunakan kayu damar.

4. Lantai indoor menggunakan kayu Sonokeling.

\subsection{Analisis Pengolahan Kontur}

Pertimbangan pengolahan kontur didasarkan pada pengembangan mengikuti eksisting kontur dalam kawasan.

Gambar 10 menunjukkan garis kontur pada lahan potensial dipertahankan untuk menjaga keaslian kawasan serta dimanfaatkan untuk pembagian zona kawasan.

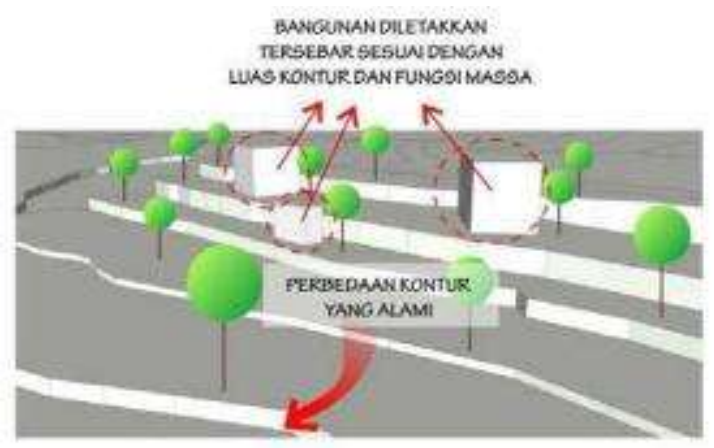

Gambar 10. Penataan Masa Pada Lahan Berkontur

Sumber. Dewi Saraswati, 2015

Upaya dalam mempertahankan kontur asli tapak juga dilakukan dengan penggunaan konsep struktur bangunan panggung, selain mampu menjaga keaslian kontur tanah juga dapat mengurangi perkerasan terhadap tanah sehingga dapat mempertahankan daerah peresapan air.

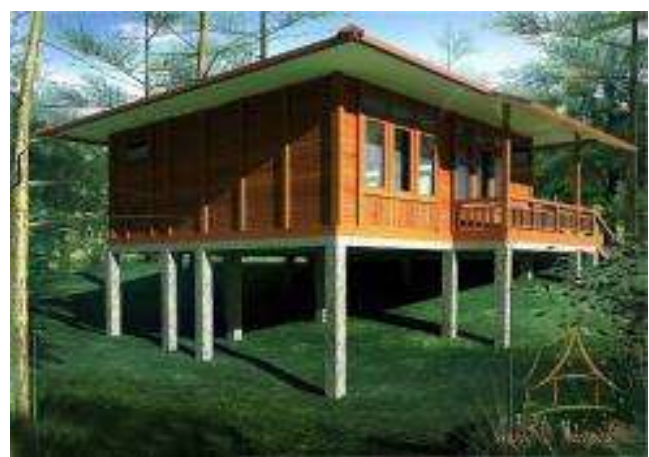

Gambar 11. Bangunan Panggung 
Gambar 11 menunjukkan perletakan bangunan panggung pada tapak berkontur.

\subsection{Analisis Utilitas Pengelolaan Air 3.7.1Jaringan Air Bersih}

Air bersih pada bangunan Hotel Resort diperoleh dari air sumur (artesis) berasal dari dalam tanah yang dipompakan ke atas.

\subsubsection{Jaringan Air Kotor} yaitu :

Air kotor diklasifikasikan menjadi empat,

a. Black water (air kloset).

b. Grey water (air dari bak mandi, dapur).

c. Air hujan.

Air kotor sebagai air buangan tidak semata-mata hanya akan dibuang, air kotor dapat diolah kembali sebagai air bekas layak pakai yang dapat digunakan kembali untuk menyiram tanaman atau sebagai flushing kloset.

Berbeda dengan black water dan grey water, air hujan akan diolah sendiri untuk dapat dimanfaatkan kembali menjadi air bersih.

\section{KESIMPULAN (KONSEP DESAIN)}

Hotel Resort di Kota Batu Malang termasuk dalam jenis Resort pegunungan yaitu terletak di kaki Gunung Welirang dan Gunung Arjuno dengan kondisi udara sejuk dan cenderung dingin. Terdapat pula beberapa area wisata pendukung yaitu Selecta, kebun bunga, kebun apel, dan lain sebagainya. Hotel Resort termasuk dalam klasifikasi Hotel Resort bintang 4. Dengan standar minimum jumlah kamar standar 50 kamar dengan luasan minimum $24 \mathrm{~m}^{2}$ per kamar, kamar suite minimum 3 kamar dengan luasan minimum 48 $\mathrm{m}^{2}$ per kamar, dan kamar mandi terdapat di dalam kamar. Memiliki fungsi sebagai tempat rekreasi dengan segala fasilitas yang disediakan, serta sebagai tempat istirahat sekaligus persinggahan bagi wisatawan yang juga ingin melakukan kegiatan lain di Kota Batu, mengingat letak Hotel Resort yang berdekatan dengan berbagai area wisata di Kota Batu Malang.

Konsep rancangan Hotel Resort mengacu pada prinsip Arsitektur Ekologis guna menjaga keberlanjutan dalam memelihara kelestarian lingkungan alam Kota Batu. Dikarenakan keindahan alam pegunungan, kesejukan udara, serta kualitas mata air yang dimiliki Kota Batu merupakan daya tarik utama wisatawan di Kota ini. Terdapat empat prinsip Arsitektur Ekologis yang diterapkan dalam desain Hotel Resort, antara lain yaitu:

1. Ramah Lingkungan.

2. Hemat Energi.

3. Pemeliharaan Sumber Lingkungan.

4. Menggunakan Teknologi Sederhana.

Berdasarkan hasil analisis serta hasil korelasi dari beberapa data di atas, diperoleh hasil berupa rancangan Hotel Resort di Batu Malang sebagai berikut:

Nama Bangunan : Hotel Resort

Lokasi : Jl. Arjuno, Desa Tulungrejo, Kecamatan Bumiajim Kota Batu. Luas Lahan : $\pm 29.360,461 \mathrm{~m}^{2}$, Luas Bangunan : $\pm 14.503,259 \mathrm{~m}^{2}$ Kegiatan : Akomodasi dan rekreasi berupa area olahraga berbasis alam.

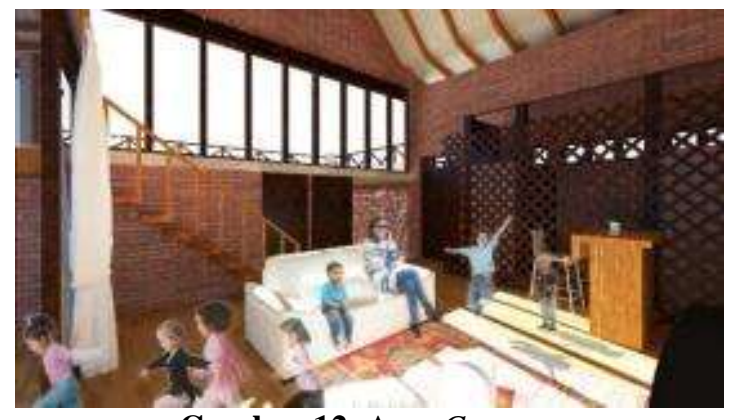

Gambar 12. Area Cottage

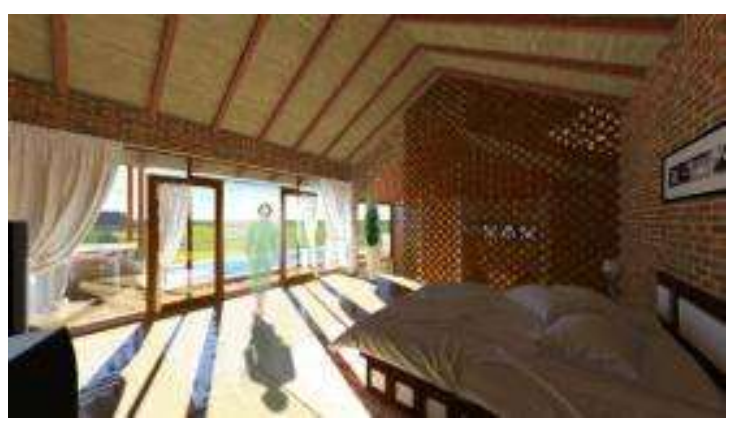

Gambar 13. Area Cottage

Gambar 12 dan 13 menunjukkan area istirahat berupa cottage yang berhubungan langsung dengan alam terbuka. Bukaan pada bangunan mampu mengurangi penggunaan pencahayaan buatan sehingga menghemat penggunaan energi listrik. 


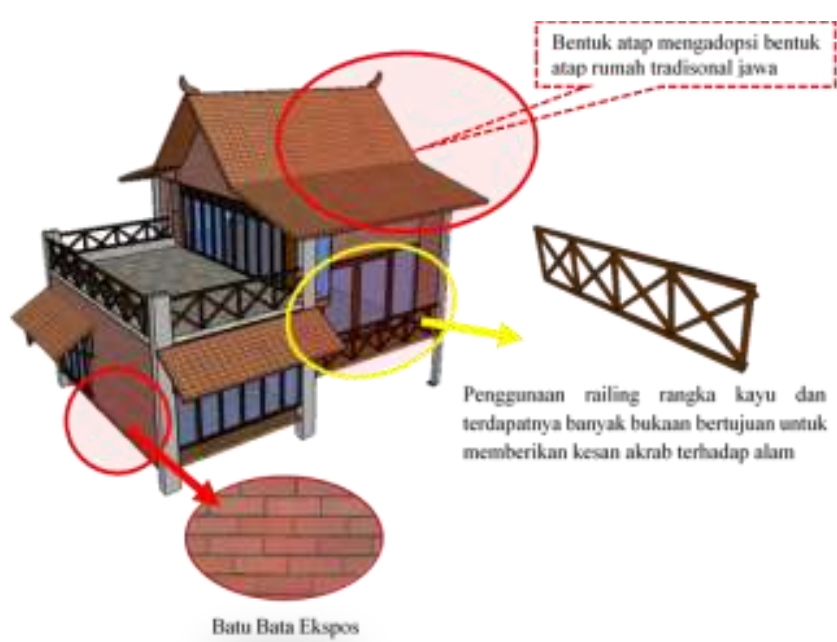

Gambar 14. Penggunaan Material Bangunan

Bangunan Hotel Resort menggunakan sistem struktur bangunan panggung dengan tujuan mengurangi perkerasan pada tanah sehingga memperluas daerah peresapan air. Penerapan prinsip Arsitektur Ekologis juga terletak pada penggunaan material bangunan (lihat Gambar 14).

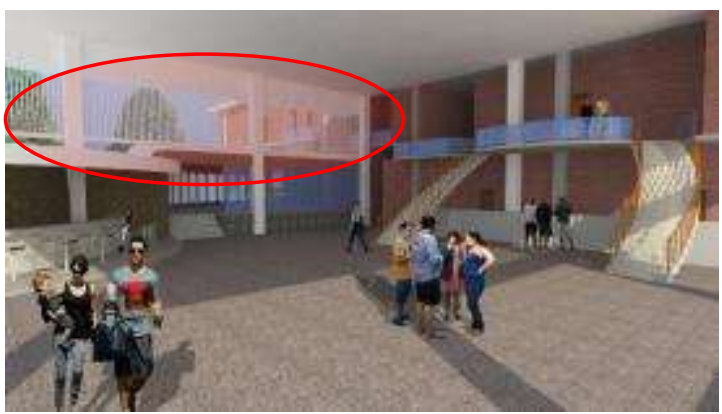

Gambar 15. Pereduksi Silau Matahari
Secondary skin digunakan sebagai pereduksi silau matahari pada bangunan (lihat Gambar 15).

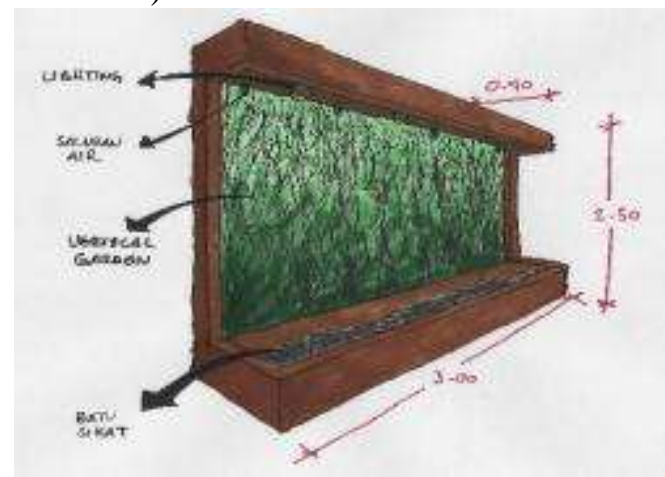

Gambar 16. Taman Vertikal

Bukaan dan taman sebanyak mungkin di terapkan pada Hotel Resort (lihat Gambar 16)

\section{REFERENSI}

Badan Pusat Statistik 2015. Statistik Perhotelan Kota Batu. Batu : BPS

Dewi Saraswati. 2015. Hotel Resort Telaga Sarangan dengan Pendekatan Arsitektur Ekologi. Tugas Akhir pada UNS Surakarta: Tidak diterbitkan

Frick H., dan FX Bambang Suskiyanto, (1998), Dasar-dasar Eko-arsitektur. Yogyakarta: Kanisius

Ngalamedialabs. 2013. Geografi Kota Batu. (online).

Tersedia: http://ngalam.id/read/1158/geografi-kotabatu/ (4 Mei 2016) 
LAMPIRAN
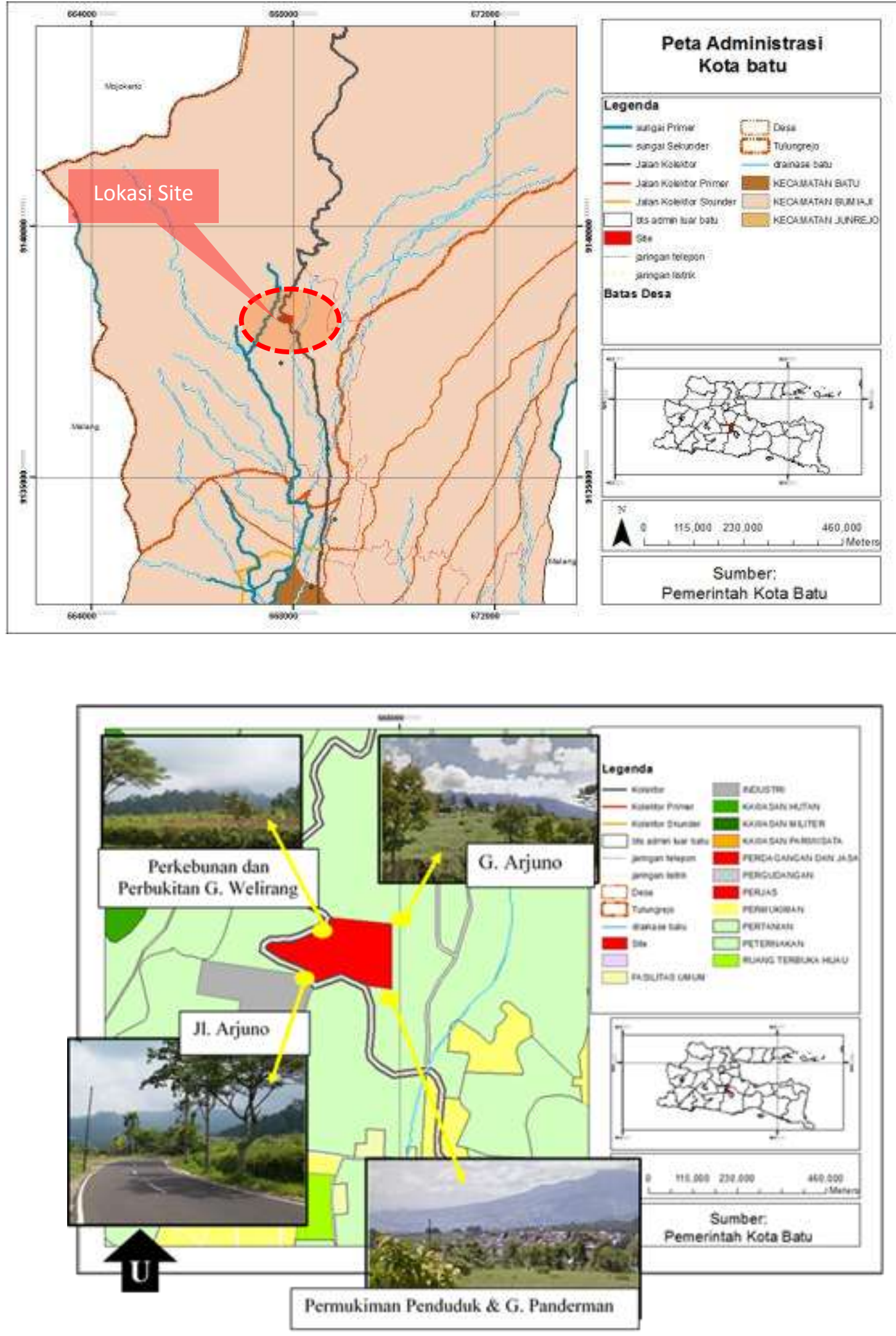